\title{
Determinants of Internet Banking Adoption by Banks in Pakistan
}

\author{
Muhammad Ali Raza ${ }^{1, *}$, Muhammad Naveed ${ }^{2} \&$ Shoaib Ali $^{3}$ \\ ${ }^{1}$ Lahore Business School, University of Lahore, Pakistan \\ ${ }^{2}$ LBS \& Bahria University, Pakistan \\ ${ }^{3}$ Air University, Pakistan \\ *Correspondence: Lahore Business School, University of Lahore, Pakistan. E-mail: Khawajaqau6@yahoo.com
}

Received: August 1, 2017

Accepted: September 14, 2017 Online Published: October 25, 2017

doi:10.5430/mos.v4n4p12

URL: https://doi.org/10.5430/mos.v4n4p12

\begin{abstract}
Current study has been conducted to determine the factors those affect the internet banking adoption decision of banks in Pakistan. Logit Probit has been used to analyze the Panel data of twenty five banks in Pakistan, covering the financial year of 2006 to 2015. The results showed that six variables deposits, expenses, market share, spread and wages found significant association with internet banking adoption decision but others were found insignificant. Study found that most of the factors have affected the adoption decision of banking industry in Pakistan.
\end{abstract}

Keywords: banking; internet; financial services; virtual banking; Pakistan

\section{Introduction}

The advent of E-banking can be seen back in 1990, when very first digital banking facility was provided by Wells Fargo bank of California (Aggelis, 2005). Later on after few years bank located in USA named security First Network Bank, has started to provide full-fledged E-banking to its customer (Grandy, 1995). Today in most of the developed and developing countries financial institutes are providing digital banking facilities to their consumers (Lassar et al, 2005). Internet banking is very in-expensive, which is very important for growth and stability of the banks (Burnham, 1996). Like most of studies Shih \& Fang(2006) also said that E-banking is advance type of information system that uses internet WWW and other many advanced technologies.

Financial entities are now adopting automated services providers like, ATM (Automated Teller Machine), websites, mobile banking etc. Websites of the banks are very important because when detailed information regarding products and services will be available at their websites it will be easy for customers to choose and use the service. Because now a day's website plays a role of branch for customer, where customer visits the website instead of physical visiting the branch and communicates with the bank (Chaffey et al. 2006). Now in the whole world businesses are using electronic commerce to run their operations (Ahmed, 2006). Banks should altered their systems and procedures to the new technological environment in order to compete with digital world (Sadiq-Sohail \& Shanmugham 2003).

One of the major forces behind the changes happening to business today is technology, which is creating new products, services market opportunities and developing more information and system oriented business and management processes. Arrival of internet has provided many opportunities of drastic changes in the procedures and working of businesses. Banks are the service industry and they are information-intensive diligence so that's why they have been affected a lot by internet and advancement in information technology. It is also important to note that provision of internet services to whole economy affected the economy at both micro and macro levels. Researchers suggested that for the economic progress transmission of internet is necessary (Pilat \& Lee, 2001; Akhavein et al., 2001; Sullivan \& Wang, 2005).

A strong and dynamic banking system is very essential for economic development and growth of any country in the world (Economic Survey, 2013-14). Internet banking has affected and altered the way of businesses. Now customers are adopting the ways of online purchasing in developing countries like Pakistan, which is providing them variety of products and services. Technological advancement is not only providing efficient and speedy services, it also decreases the cost of businesses. Banking industry is one of the pioneer industries in adopting internet banking and it 
is very best for this sector (Kardaras \& Papathanassiou, 2001).

E-banking has changed the way of working in the financial sector by providing advanced and modern methods. Internet banking delivered better and quality services to ultimate consumer and get its benefits for long period of time. It is also important to mention here that E-banking is not a substitute of traditional way of banking but it can be differing from old banking in terms of quality services. Researcher also said that saving banks were among the early adopted of internet banking (Corrocher, 2002).

Research studies on financial innovations like (Akhavein, 2001; Apaka, 2012; Buzzacchi, 1995; Courchane, 2002; Nickerson, 2003). Most of the studies has analyzed the financial advancement through quantitative methods from recent studies like, (Bughin, 2001; Furst et al. 2000; Sullivan, 2000; DeYoung, 2005; Akhavein et al., 2001; Courchane et al. 2002; Hasan et al., 2002; Nickerson \&Sullivan, 2003; Sullivan \& Wang, 2005; Hannan \& Mcdowell, 1987). Some of the studies have analyzed the effects of internet banking, financial innovation and advancement on performance of banks like, (DeYoung, 2001, 2005 \& 2007; Nolle, 2007; Sullivan, 2000).

Due to modern era demand for internet banking has been increased, so that's why this topic has gained a lot of attention of researcher. But literature on internet banking mostly available in developed countries like USA, Italy, Turkey, Malaysia and many other European countries. In Pakistan most of the studies were conducted from customer's point of view and this study is first one which has focused bank's prospective in adoption decision. This paper has been divided in five sections; second section discusses the available literature on internet banking adoption. Third section provides data and explanatory variables and their expected results. Fourth section includes results and fifth section delivers findings of the paper.

\subsection{Significance}

The word "Internet-Banking" is now become very attractive in all over the world. But In Pakistan internet banking is still struggling for its growth. It has connected the whole world and a businessman wherever he is living can do his business transaction through these digital methods. Now the whole world is in competition, everyone wants to beat his rival by providing in-expensive and better services to expand his business (Lucking-Reiley\&Spulber, 2001).

Main rational behind this study is to analyze the factors those affecting the banks adoption decision of internet banking in Pakistan. Consistent with previous literature and to check these factors, some questions has been formed to check the effects of these factors on adoption decision. Practically this study will help to Banks to form their policy regarding Internet Banking adoption. Secondly, it will also helpful for State Bank of Pakistan to check and regulate the Internet Banking and make laws to enhance the Internet banking adoption process.

\subsection{Problem Statement}

In literature review a lot of studies have been found those analyzed the performance of banking industry and also check internet banking adoptability. But all of these studies focused on customer's preferences. To the best of my knowledge no one has analyze from bank's perspective in Pakistan. This study will analyze the effects of different factors like, deposits, expenses, market share, spread, wages, Age, Branches, ROA and size on adoption decision of Internet Banking of banks in Pakistan. So the problem statement is to determine the factors those affected the Internet Banking adoption decision in Pakistan.

\subsection{Objective}

Main purpose of this study is to check the influence of different factors like, deposits, expenses, market share, spread, wages, Age, Branches, ROA and size on adoption decision of Internet Banking of banks in Pakistan.

\section{Literature Review}

After the independence of Pakistan there was no proper banking system exist in the country. After that State Bank of Pakistan (Central Bank) has been established on $1^{\text {st }}$ july 1949 . Main functions of a central bank in a country to observe and control all the activities of banking sector and to also formulate policies, rules \& regulations for smooth working of banking sector in the country. So that's why State Bank of Pakistan also set guidelines in the name of prudential regulations to control, monitor and regulate the banking sector in the country (Hussain, 2006).

E-banking has changed the way of working in the financial sector by providing advanced and modern methods. Internet banking delivered better and quality services to ultimate consumer and get its benefits for long period of time. It is also important to mention here that E-banking is not a substitute of traditional way of banking but it can be differing from old banking in terms of quality services. Researcher also said that saving banks were among the early 
adopted of internet banking (Corrocher, 2002).

In Pakistan internet banking was introduced by foreign banks in 1990s. Firstly they have introduced ATM (Automated Teller Machine) and then credit, Debit cards was introduced. These products were new at that time and people in the big cities of Pakistan also demanded these products from domestic banks. So to remain competitive and in line with industry, domestic banks also invested in internet banking in 1990s (Shamim, \& Sardar 2010).

The last decade, especially the second half, is characterized by various advanced technological adoptions by banks, for example, E-Banking, Automated Teller Machines (ATMs), Credit Cards, M-net, Society for Worldwide International Facilitation Transfers (SWIFT), National Institutional Facilitation Technologies (NIFT), etc. The aim of adopting advanced technologies, despite bearing the heavy fixed cost for it, was to speed up the process of financial transactions through broad automated networking that resulted in low transaction cost per unit as well as customer facilitation in terms of fast human interaction.

In early 2000 Govt. of Pakistan has taken steps to link business, commerce and other social activities with internet. In these days commercial banks were leading the show by providing innovative and advanced products to its customers. Govt. of Pakistan also took initiative to make regulations for the adoption of these advanced technologies which helped the private as well as foreign banks to participate in the race of internet banking (Ahmed, 2006). When we talk about technological growth in Pakistan it is very sad to know that we cannot even compare technological growth of Pakistan with other developing countries. Technological improvement system is very slow in Pakistan (Khan \& Bawden, 2005).

To meet the technological demands of public and also for the speedy growth, seven IT specialized universities and one virtual university was established in Pakistan to produce more professional and qualified personnel. And continuation of these efforts has been found in our long-term education policy of 1998-2010. Main objective of this policy was to ensure that every student should learn about computer technology. Most of the foreign well reputed IT companies are also investing in our Information technology sector of Pakistan for the improvement and growth of this sector (Shahzada, 2006).

Pakistan is adopting internet banking in a speedy way (Shamim \&Sardar,2010). Due to the importance and increasing needs of internet banking it is also become very necessary to find out what the major factors those are forcing the banking industry of Pakistan to adopt internet banking. So that's why growing demands and importance of internet banking there are a lot of studies have been done to explore the forces which are forcing the banks to adopt internet banking.

Due to the importance and increasing needs of internet banking it is also become very necessary to found out what the major factors those are forcing the banking industry of Pakistan to adopt internet banking. So that's why growing demands and importance of internet banking there are a lot of studies have been done to explore the forces which are forcing the banks to adopt internet banking.

In Italy research concluded that internet banking is not a substitute to conventional banking but this new way of banking have feature of providing services in flexible ways. Saving banks were the pioneer in adopting internet banking services in Italy, only twenty percent were offering internet banking services in 1999 and most of them were larger banks among internet banking services provider. A small number of small banks were providing internet banking services. For internet banking provider main objective was not to earn a lot of money or yield there focus was just to capture new customers and to retain their existing base (Corrocher, 2002).

Results of the study described that there were small number of banks those were working efficiently by adopting internet bank services but most of them adopted both strategies (Sargua, Mehdianb \& Stoicaa, 2013). According to Giglio (2002) \& Robinson (2000), if a bank wants to deliver its products to its customer in an in-expensive way then online banking will be very best choice. Conventional banks showed a remarkable support for cost effectiveness and internet service provider were affecting Return on assets and Return on equity (Delgado, Hemando \& Nieto 2007). Internet banking is not a substitute it is become compulsory for a bank to adopt internet services if it want to remain in the market (Nolle, Lang \& DeYoung 2007).

Hanafizadeh, Keating \& Khedmatgozar, (2014) have studied different papers on internet banking and gives summary of research articles. They focus on past papers published from 1999 to 2012. IB adoption is very important advancement in banking industry and now become very interesting and popular topic in research. This will remain topic of interest in future. They have analyzed that data on IB adoption can be distribute in three categories Descriptive, Relational and Comparative. They have analyzed 165 articles and results indicated that IB will remain significant topic in future. In past relational studies were adopted by the researcher now research indicated that now 
focus will be shifted to comparative studies. They also examined that this study has been conducted in three region ASIA, EUROPE and AMERICA.

Internet Banking has positively affected the profitability of Banks in both developing and developed countries (Ilyas Akhisar, Batu Tunayb \&Necla Tunaya 2015). Positive relationship has been found between high profits and adoption decision. Banks those were generating high profits have adopted internet banking most due to retain their existing customers but they were not among the early adopters (Furst, Lang \& Nolle, 2000).

\subsection{Research Questions}

1. How Size, Age and Branch intensity of banks affect their decision to go for innovation?

2. Whether reduction in fixed expenses and Wages expenses attracted banking industry to go for digitalization?

3. What will be effects of ROA and deposits on internet banking adoption decision?

\section{Methodology}

\subsection{Data and Explanatory Variables}

Unit of analysis for this study is the Banking industry of Pakistan and twenty five banks have been included in the study which consists of Private, Public, Foreign and Islamic. We have taken only those banks which were established before or on 2006. Our sample is consisting on data ranging from 2006 to 2015. So that's why we have excluded some newly established banks and foreign banks those started their operations in Pakistan after 2006. Secondary data collected from Financial Statements, Annual reports of Banks and also from SBP's website in Pakistan for the period of 10-years. Logit Probit Model (in line with previously used by many other researchers) has been applied to check the effects of these factors on Internet banking adoption decision.

\subsection{Explanatory Variables}

First variable of interest is the AGE of a bank. According to the existing literature this variable expected to be negatively related with internet banking adoption decision. Because newly established banks easily adopt new and innovative products to increase their businesses and customer base, in comparison with old banks because they have legacy and traditional system and it is difficult to change or adopt new policy in these organizations. Because they have to face many obstacles during change process. (Ang \& Koh, 1997; Sullivan \& Wang, 2005) have used this variable in their research.

Second variable of interest is BRANCH intensity. This can also be a strong factor which has changed the direction of banking towards digital banking. Opening of new branch is very long and systematic process. There are opportunities for both those have large number of branches they can adopt internet banking as a measure to stop investing in opening of new branches by expanding their business through internet. Second those have less number of branches can take advantage of this modern technology because it is inexpensive way of expanding their businesses (Furst et. Al., 2001, 2002 Andriy 2001).

Third variable of discussion is DEPOSITS. Deposit is most important variable of banking literature, because banking without deposit is nothing. And without focusing on deposit we cannot complete our analysis on banks. Major and most important function of banks has to collect deposits. So we can say here that banks changes its policies and way of working to attract deposits. Andriy (2001) concluded in his study that deposits have positive effect on internet banking adoption decision.

Fourth factor which we have focused is EXPENSES. Expenses of fixed assets like furniture, building etc. By adopting internet banking expenses for fixed assets can be reduced. Internet banking is cheap enough as compared to traditional branch banking. So that's why it can affect the decision of internet banking adoption. But most of the researcher found no relation between internet banking adoption and reduction in fixed assets expenses. They also mentioned that during 2000s a remarkable expansion has been noted in number of bank branches in US (Nolle, Lang \&DeYoung 2006).

Another most important element of this study which we have to study is MARKET SHARE. Every business organization wants to increase their market share. Success of an organization can be measured through his market share in the industry. Most of the studies have suggested that expansion in market share of bank compel banks to adopt internet banking to retain their customer base (Courchane et al.., 2002).

Basic purpose of a commercial organization is to earn profit. All policies and regulations made in these organizations to increase their profits. So that's why earning can be a major factor which can affect the policies of organization. So 
that's why we have also select ROA variable to check its effects on decision making of banking industry in Pakistan. Most of profitable banks can go for internet banking because it can be helpful for them in two ways first of all it can help them to retain their profitability position and secondly financially strong banks can easily incurred expenses on internet banking. So that's why sign of effect is ambiguous for ROA whether it will affect the internet banking decision in Pakistan or not. Most of the studies have included this ROA factor in their studies in different countries to check its effect on internet banking decision and they have concluded that this factor has not affected the internet banking decision of banks (Bughin, 2001; Corrocher, 2002; Buzzacchi et al., 1995; Gourlay and Pentecost, 2005).

At number seven we have included SIZE factor to analyze its impact on internet banking adoption decision in Pakistan. SIZE can be measured as natural log of total assets. One research study has described that there is mindset that larger and big organization supports he changes in technology structure or in people due to their larger setups and economy of scale. Because larger and big organizations have mostly research \& development departments which help them to decide whether going for innovation will be beneficial for organization or not (Buzzacchi et al., 1995).

SPREAD is the gross profit for banking industry. Banks makes their policies to increase their interest income and also take measures to decrease their cost of fund and interest expenses. So when a bank will provide better services and products to its customers ultimately its customer base will be increased and his earning will be increased. So spread can be a major factor in deciding whether to go for internet banking or not. Most of studies have studied only ROA and ROE in their papers and tried to find out their relationship with internet banking adoption decision. So now we have also considered this important variable in our study and expecting a positive relationship with internet banking adoption decision by banks in Pakistan.

In last WAGES has been included in our model. Most of the studies has included because when an industry shifts its working from manual to computer we have seen a lot of reduction in their labor and personnel. Because computer can work more rapidly and accurately as compared to human. So when number of employees will be decreased in an organization ultimately wages will be reduced. So it can be a major factor which can attract banking industry to go for internet banking. Wages reduction has been found a major element to go for internet banking adoption in most of the countries (Hannan \& Mc Dowell, 1984; Sharma, 1993; Gretton et al., 2003; Sinha and Chandrashekran. 1992; Gourlay and Pentecost. 2005).

\subsection{The Model}

For the analysis of factors affecting bank's decisions of going for internet banking. Logit Probit can be estimated with the dependent variable of "INTERNET" which takes on a value of " 1 " if banks had adopted internet banking from 2006 to 2015, otherwise zero. A bank will be considered internet bank which has adopted internet banking by December 2015. Variables of the proposed model have been discussed in below.

Internet Adoption $=\beta 1_{\mathrm{i}}+\beta 2 \mathrm{Age}_{\mathrm{it}}+\beta 3 \mathrm{Bran}_{\mathrm{it}}+\beta 4 \mathrm{Dep}_{\mathrm{it}}+\beta 5 \mathrm{Exp}_{\mathrm{it}}+\beta 6 \mathrm{MS}_{\mathrm{it}}+\beta 7 \mathrm{ROA}_{\mathrm{it}}+\beta 8 \mathrm{Size}_{\mathrm{it}}+\beta 9 \mathrm{Spd}_{\mathrm{it}}+\beta 10 \mathrm{Wag}_{\mathrm{it}}+\mu_{\mathrm{i}}$

Where:

- $\quad \beta 1, \beta 2 \ldots \beta 10$ are the coefficients to be estimated;

- $\quad \mu_{\mathrm{i}}$ is a disturbance term

4.3.1 Dependent Variable:

Internet [Dummy for the Banks who have adopted Internet Banking by December 2015.]

4.3.2 Independent Variables:

Age [The Natural Log of The number of Years from the date of Incorporation to the last year of analysis. i.e. 2015].

Branches [The ratio of number of Branches to Total Assets].

Deposits [The ratio of Deposits to Total Funds].

Expenses [The ratio of expenses for premises and fixed assets to net operating revenue].

Market Share [Loans and Investments of Total Banks].

ROA [The ratio of average net profits to average assets].

Size [The natural Log of the total assets].

Spread [Log of Net Interest Income].

Wage [The ratio of Total Labor expenses to total number of employees]. 


\section{Findings}

4.1 Table No.1

Dependent Variable: INTERNET

Method: ML - Binary Logit (Quadratic hill climbing)

Date: 01/08/17 Time: $15: 40$

Sample: 20062015

Included observations: 250

Convergence achieved after 7 iterations

Covariance matrix computed using second derivatives

\begin{tabular}{|c|c|c|c|c|}
\hline$\underline{\text { Variable }}$ & Coefficient & Std. Error & z-Statistic & Prob. \\
\hline $\mathrm{C}$ & -6.788189 & 3.606639 & -1.882137 & 0.0598 \\
\hline AGE & -0.000594 & 0.005264 & -0.112829 & 0.9102 \\
\hline BRANCHES & 102.6183 & 161.0343 & 0.637245 & 0.5240 \\
\hline DEPOSITS & 7.640615 & 1.314560 & 5.812298 & 0.0000 \\
\hline EXPENSE & 0.564062 & 0.230883 & 2.443066 & 0.0146 \\
\hline MARKET & -19.22157 & 6.645914 & -2.892239 & 0.0038 \\
\hline ROA & 7.334165 & 7.860539 & 0.933036 & 0.3508 \\
\hline SIZE & -0.332031 & 0.557066 & -0.596034 & 0.5512 \\
\hline SPREAD & 0.747779 & 0.292702 & 2.554747 & 0.0106 \\
\hline WAGES & 0.001569 & 0.000621 & 2.527439 & 0.0115 \\
\hline McFadden R-squared & 0.304549 & \multicolumn{2}{|c|}{ Mean dependent var } & 0.760000 \\
\hline S.D. dependent var & 0.427940 & \multicolumn{2}{|c|}{ S.E. of regression } & 0.348775 \\
\hline Akaike info criterion & 0.846498 & \multicolumn{2}{|c|}{ Sum squared resid } & 29.19456 \\
\hline Schwarz criterion & 0.987357 & \multicolumn{2}{|c|}{ Log likelihood } & -95.81230 \\
\hline Hannan-Quinn criter. & 0.903190 & \multicolumn{2}{|c|}{ Restr. log likelihood } & -137.7700 \\
\hline LR statistic & 83.91537 & \multicolumn{2}{|c|}{ Avg. log likelihood } & -0.383249 \\
\hline Prob(LR statistic) & 0.000000 & & & \\
\hline Obs with Dep=0 & 60 & \multicolumn{2}{|c|}{ Total obs } & 250 \\
\hline Obs with Dep=1 & 190 & & & \\
\hline
\end{tabular}

Results of logit estimation are given in (table 1) in which first of all AGE has been listed. From table 1 we can see that coefficient of the variable is positive and insignificantly related to Internet banking. Here our hypothesis for Age has been rejected because these results indicate that older banks have adopted internet banking rapidly as compared to new banks. Because older banks had a suitable and large customer base. So that's why due to competitors pressure and technology advancement it compels old banks to adopt internet Banking to retain their existing customer base and also to capture new customers. Our results contradict with the findings of work done on internet banking adoption decision in India that new banks were offering internet banking services rapidly as compared to old banks (Malhotra, 2007). Another study also found no relation between AGE and internet banking adoption decision of banks (Delgado, Hemando\& Nieto 2007).

Second most important variable of the study was BRANCH intensity. We raised question mark on its effects because we were not clear about its effects. Now in the above results we can see that it is positively but insignificantly related with Internet adoption. It means that in Pakistan banks those have large number of branches they are still focusing on branch services as compared to Internet services. We can say that banks those have large number of branches not 
focusing on Internet Banking as key factor to serve the customer. And here we can also conclude that banks those have small number of branches are totally focusing on Internet Banking for attracting more customers. Internet banking is cheapest way of providing bank services to their customers Nolle, Lang, \& DeYoung (2006).

Third variable of our study was DEPOSITS, and in (table 1) results showed that DEPOSITS is positively and highly significant effected the Internet Banking adoption in Pakistan. This number shows that all banks whether they are small, big, private or public, have adopted Internet Banking as complementary for expansion of their deposits. In banking industry deposits plays very important role. Major functions of banking are to attract deposits from general public and sanction loans. Major source of earning of banking industry is the difference between deposit rate and lending rate. So when a bank will have strong deposit position definitely it will finance a large amount and will earn more profit. So that's why deposit is the blood for banking industry.

We can derive a conclusion from above discussion that Deposits played a vital and effective role in adoption of Internet Banking in Pakistan. These results regarding deposits are in line with the study conducted in India on internet banking adoption decision (Malhotra, 2007). But contradicts with the study conducted in US by Furst et.al.(2000).

Fourth variable of interest in our study was EXPENSES for fixed assets. Results of this variable are consistent with our hypothesis and positively related with Internet Banking. It means we can say that Banks see Internet Banking as a major factor to reduce their expenses for fixed assets. By adopting Internet Banking banks can reduce their costs for opening of new branches, fixing of fixed assets. Our results for EXPENSES are in line with the study conducted in India that reduction in fixed assets expenses is very major and attractive variable influence the adoption decision. (Malhotra, 2007).

MARKET SHARE was also key variable in determining the effects on adoption decision. Coefficient turns to be negative and in line with our assumption that Banks those have low market share are adopting Internet Banking rapidly to increase their market share in all segments. Because Internet Banking is very cheap and easy way to increase Market share of the bank. Our results are similar with the study of (Malhotra, 2007).

ROA (Return on Assets) variable included to check whether it has independent effect on Internet Banking adoption. According to the results this variable has insignificant relation with Internet Banking adoption. It means that this variable has not affected the decision of Internet banking adoption by Banks in Pakistan. We can also say that increasing in return was not primary objective of the Banks those have adopted Internet banking in Pakistan.

Next variable of discussion is SIZE; we assumed that this will be positively related with Internet Banking adoption decision. In our results it has negatively and insignificantly affected the Dependent variable. It is not in line with our hypotheses and it is also not matched with the study of Malhotra 2007. From above results we can say that small banks are not rapidly adopting and offering internet banking services as compared to larger banks.

Most important variable and factor for banking industry is Spread. Because it is Gross Profit of Banking Industry. We included this variable to check whether Internet banking adoption has been affected by this variable or not. We were not clear about its effects whether it will affect internet banking decision or not. Now according to the above results we can see that Spread is positively and highly significant related with the adoption decision. It means that banks those have high spread have rapidly adopted Internet Banking to decrease their expense and to increase their net income.

Last variable of interest was wages and it was hypothesis that this variable will positively affect the IB. Results of this variable are consistent with our assumption. It has positive and significant relation with internet banking adoption decision by banks in Pakistan. It means that if a bank has incurred a lot of expenses in personnel administration then it will encourage the banks to go for internet banking adoption as compared to those who have not beard these expenses.

\subsection{Descriptive Analysis: Pattern of Data Distribution}

In the (Table No. 2) pattern of data distribution has been calculated with the help of central tendency (Mean, Median, Maximum, and Minimum) and measures of dispersion (Standard deviation, Skewness, Kurtosis, Jarque-Bera, Probability, sum of squared deviation). To check the skewness of data the rule of thumb is that if it has positive values, data will be positively skewed and will be negatively skewed if it will pertain negative values. AGE, Branches, Expenses, Market, ROA Size and Wages are positively skewed while Internet, deposit and spread is negatively skewed. 
Table 2. Descriptive Analysis Table

\begin{tabular}{|c|c|c|c|c|c|c|c|c|c|c|}
\hline & INTERNET & AGE & BRANCHES & DEPOSITS & EXPENSE & MARKET & ROA & SIZE & SPREAD & WAGES \\
\hline Mean & 0.760000 & 36.752 & 0.000415 & 0.671440 & 1.554160 & 0.035923 & 0.007251 & 8.10340 & 6.492020 & 711.628 \\
\hline Median & 1.000000 & 21.000 & 0.000110 & 0.740000 & 0.505000 & 0.019675 & 0.008127 & 8.20500 & 6.676000 & 628.640 \\
\hline Maximum & 1.000000 & 203.00 & 0.020000 & 0.910000 & 176.4700 & 0.154840 & 0.371871 & 9.35000 & 7.885000 & 3077.07 \\
\hline Minimum & 0.000000 & 0.0000 & 0.000000 & 0.030000 & -2.950000 & 0.000200 & -0.316204 & 6.60000 & 0.000000 & 0.00000 \\
\hline Std. Dev. & 0.427940 & 40.130 & 0.001944 & 0.204757 & 11.16356 & 0.040941 & 0.037830 & 0.63172 & 1.166620 & 401.340 \\
\hline Skewness & -1.217562 & 2.6303 & 8.156684 & -1.637470 & 15.47997 & 1.473853 & 1.503650 & -0.35123 & -3.520855 & 1.83501 \\
\hline Kurtosis & 2.482456 & 10.889 & 73.36429 & 4.922542 & 243.0239 & 4.183905 & 59.76279 & 2.28534 & 20.03591 & 8.54652 \\
\hline Jarque-Bera & 64.55913 & 936.72 & 54346.45 & 150.2229 & 610104.2 & 105.1105 & 33656.86 & 10.4604 & 3539.667 & 460.760 \\
\hline Probability & 0.000000 & 0.0000 & 0.000000 & 0.000000 & 0.000000 & 0.000000 & 0.000000 & 0.00535 & 0.000000 & 0.00000 \\
\hline Sum & 190.0000 & 9188.0 & 0.103700 & 167.8600 & 388.5400 & 8.980790 & 1.812748 & 2025.85 & 1623.005 & 177907.0 \\
\hline SumSq. Dev. & 45.60000 & 400994.00 & 0.000941 & 10.43948 & 31031.63 & 0.417365 & 0.356347 & 99.3686 & 338.8893 & 4010736 \\
\hline Observation & 250 & 250 & 250 & 250 & 250 & 250 & 250 & 250 & 250 & 250 \\
\hline
\end{tabular}

Jarque-bar test follows the Chi-Square distribution pattern to check the distribution pattern of the data. Null hypothesis of jarque-bar test is data is normally distributed. If the value of JB test tends more towards Zero, null hypothesis will be rejected. It can be derived from above presented results in the table that except one variable no one was normally distributed. So that's why mathematical transformation was required. In this study Internet was Dependent variable was transformed to dummy variable by assigning them 1 and 0 .

The ideal value of Kurtosis should be equal to 3. And most of the observations have the values of more than 3 . When values falls in more than 3 it means most of the values falls in the tails of normal curve. When data falls in the tails of normal curve then problem of outlier increase so that's why through transformation of dummy variables this problem will be reduced.

\subsection{Correlation}

Table 3. Correlation Table

\begin{tabular}{|c|c|c|c|c|c|c|c|c|c|c|}
\hline & AGE & BRANCHES & DEPOSITS & EXPENSE & INTERNET & MARKET & ROA & SIZE & SPREAD & WAGES \\
\hline AGE & 1 & & & & & & & & & \\
\hline BRANCHES & 0.024046 & 1 & & & & & & & & \\
\hline DEPOSITS & -0.18337 & 0.008933 & 1 & & & & & & & \\
\hline EXPENSE & -0.06345 & -0.0089 & -0.04602 & 1 & & & & & & \\
\hline INTERNET & -0.06194 & 0.031994 & 0.470998 & 0.031516 & 1 & & & & & \\
\hline MARKET & 0.177007 & 0.10607 & 0.356972 & -0.07342 & 0.057677 & 1 & & & & \\
\hline ROA & 0.13491 & 0.031982 & 0.00998 & -0.03366 & 0.124997 & 0.186405 & 1 & & & \\
\hline SIZE & 0.099089 & 0.087777 & 0.477737 & -0.12696 & 0.183082 & 0.780868 & 0.174993 & 1 & & \\
\hline SPREAD & 0.15614 & 0.071631 & 0.199431 & -0.24387 & 0.229715 & 0.505237 & 0.41506 & 0.592189 & 1 & \\
\hline WAGES & 0.351555 & -0.05994 & -0.05707 & -0.1369 & 0.110383 & 0.110246 & 0.077548 & 0.17112 & 0.223756 & 1 \\
\hline
\end{tabular}

From (Table No.3) we examine that AGE and Branches have positive relationship, it means that by increasing the age of banks no. of branches has been increased. Branches and deposits have also a positive relationship this indicates that expansion in number of branches have positive effect on deposits of the banks. When branches will be increased it will cause to increase the deposits of banks. Deposits and expenses has negative relationship. Expenses and Internet expansion has positive relationship. Internet and market share also have positive relationship it means that by increasing the Internet based transactions and products Market shares of the banks has been increased. It indicates that Internet Banking has played a major role to expand the Market share of the banks. We can say that it is a major factor which have compelled the banks to adopt Internet Banking. Market share also have positive relationship with ROA it means that when Market share of the banks will be increased it will increase the Return on Assets. ROA has positive relationship with size that means ROA will be increased by expansion in the size. Internet has only negative relationship with the AGE this indicates that older banks were reluctant to adopt Internet Banking 
as compared to newly established business.

\section{Conclusion}

Main objective of the study was to investigate the impact of different factors on internet adoption decision of banks in Pakistan. Logit probit model has been used to analyze the panel data collected from the financial statements of banks. In Pakistan older banks adopted internet banking rapidly as compared to new established. Branch intensity factor does not affect their adoption decision. So here we can say that banks those are older, having high spread, having remarkable market share, want to decrease their expenses and to expand their deposits was much interested in internet banking as compared to newly established banks.

One of the major limitations of this study is scope and size of its variables. We have included deposit, expenses, size, age, market share and different other factors in our study. But we have not included other many factors like ownership structure and their effects on internet banking adoption decision. This can be a major factor in this segment because in public sector banks in Pakistan old legacy system exists and it can be major restriction in adoption of internet banking. This study can be helpful in policy formation regarding digitalization of banking industry in Pakistan. This study can also helpful for Bank's management for making decisions about adoption, innovation and expansion of internet banking in Pakistan.

\section{References}

Ariff, M. S. M., Yun, L. O., Zakuan, N., \& Jusoh, A. (2012). Examining dimensions of electronic service quality for internet banking services. Procedia-Social and Behavioral Sciences, 65, 854-859. https://doi.org/10.1016/j.sbspro.2012.11.210

Akhavein, J. D., Frame, W. S., \& White, L. J. (2001). The diffusion of financial innovations: An examination of the adoption of small business credit scoring by large banking organizations. (March 2001). NYU Working Paper No. EC-01-08. https://doi.org/10.2139/ssrn.267681

Apak, S., Tuncer, G., Atay, E., \& Koşan, N. İ. (2012). Insights from knowledge management to radical innovation: "Internet banking applications in the European Union". Procedia-Social and Behavioral Sciences, 41, 45-50. https://doi.org/10.1016/j.sbspro.2012.04.006

Apak, S., \& Atay, E. (2012). Eurozone debt crises versus new opportunities for global internet banking collaboration and strategic alliances in the EU and Balkan countries. Procedia-Social and Behavioral Sciences, 58, 560-568. https://doi.org/10.1016/j.sbspro.2012.09.1033

Atay, E., \& Apak, S. (2013). An overview of GDP and internet banking relations in the European Union versus China. Procedia-Social and Behavioral Sciences, 99, 36-45. https://doi.org/10.1016/j.sbspro.2013.10.469

Andriy, C. (2001). ELECTRONIC BANKING IN UKRAINE: THE FACTORS IN DECISION-MAKING (Doctoral dissertation, National University of Kyiv-Mohyla Academy).

Bughin, J. (2001). E-pull or e-push? Laggards and first-movers in European banking. Journal of Computer Mediated Communications, 7(1). https://doi.org/10.1111/j.1083-6101.2001.tb00133.x

Bughin, J. (2003). The diffusion of Internet banking in Western Europe. Electronic Markets, 13(3), 251-258. https://doi.org/10.1080/1019678032000108329

Bughin, J. (2004). The success of Internet banking: an econometric investigation of its pattern of diffusion within Western Europe. Katholieke Universiteit Leuven,[Faculty of Economics and Applied Economics], Department of Applied Economics.

Buzzacchi, L., Colombo, M. G., \& Mariotti, S. (1995). Technological regimes and innovation in services: the case of the Italian banking industry. Research Policy, 24(1), 151-168. https://doi.org/10.1016/0048-7333(93)00756-J

Colombo, M. G., \& Mosconi, R. (1995). Complementarity and cumulative learning effects in the early diffusion of multiple technologies. The Journal of Industrial Economics, 13-48. https://doi.org/10.2307/2950423

Corrocher, N. (2002). Does Internet Banking Substitute Traditional Banking?: Empirical Evidence from Italy. Università commerciale Luigi Bocconi.

Courchane, M., Nickerson, D., \& Sullivan, R. (2002). Investment in internet banking as a real option: theory and tests. Journal of Multinational Financial Management, 12(4), 347-363. 
https://doi.org/10.1016/S1042-444X(02)00015-4

Delgado, J., Hernando, I., \& Nieto, M. J. (2007). Do European primarily Internet banks show scale and experience efficiencies?. European $\quad$ Financial $\quad$ Management, $\quad$ 13(4), https://doi.org/10.1111/j.1468-036X.2007.00377.x

DeYoung, R. (2001). The financial performance of pure play Internet banks. Economic Perspectives, 25(1).

DeYoung, R. (2005). The performance of Internet-based business models: Evidence from the banking industry. The Journal of Business, 78(3), 893-948. https://doi.org/10.1086/429648

DeYoung, R., Lang, W. W., \& Nolle, D. L. (2007). How the Internet affects output and performance at community banks. Journal of Banking \& Finance, 31(4), 1033-1060. https://doi.org/10.1016/j.jbankfin.2006.10.003

Daneshgadeh, S., \& Yıldırım, S. Ö. (2014). Empirical investigation of internet banking usage: The case of Turkey. Procedia Technology, 16, 322-331. https://doi.org/10.1016/j.protcy.2014.10.098

Furst, K., Lang, W. W., \& Nolle, D. E. (2000). Who offers Internet banking?. Journal of Financial Services Research (2002), 22, 95. https://doi.org/10.1023/A:1016012703620

Furst, K., Lang, W. W., \& Nolle, D. E. (2001). Internet banking in the US: Landscape, prospects, industry implications. Capco Institute Journal of Financial Transformation, 2, 45-52.

Furst, K., Lang, W. W., \& Nolle, D. E. (2001). Internet banking: developments and prospects. SSRN Electronic Journal.

Gourlay, A. R., \& Pentecost, E. J. (2005). The impact of network effects on technology adoption: evidence from the adoption of automated teller machines. Department of Economics, Loughborough University, Loughborough.

Hannan, T. H., \& McDowell, J. M. (1984). The determinants of technology adoption: The case of the banking firm. The RAND Journal of Economics, 328-335. https://doi.org/10.2307/2555441

Hannan, T. H., \& McDowell, J. M. (1987). Rival precedence and the dynamics of technology adoption: an empirical analysis. Economica, 155-171. https://doi.org/10.2307/2554388

Hanafizadeh, P., Keating, B. W., \& Khedmatgozar, H. R. (2014). A systematic review of Internet banking adoption. Telematics and informatics, 31(3), 492-510. https://doi.org/10.1016/j.tele.2013.04.003

Keeton, W. R. (2001). The transformation of banking and its impact on consumers and small businesses. Economic Review-Federal Reserve Bank of Kansas City, 86(1), 25.

Nickerson, D., \& Sullivan, R. J. (2003). Financial innovation, strategic real options and endogenous competition: theory and an application to Internet banking. Federal Reserve Bank of Kansas City Payments System Research Working Paper PSR WP, 03-01.

Purwanegara, M., Apriningsih, A., \& Andika, F. (2014). Snapshot on Indonesia regulation in mobile internet banking users attitudes. Procedia-Social and Behavioral Sciences, 115, 147-155. https://doi.org/10.1016/j.sbspro.2014.02.423

Santouridis, I., \& Kyritsi, M. (2014). Investigating the determinants of Internet banking adoption in Greece. Procedia Economics and Finance, 9, 501-510. https://doi.org/10.1016/S2212-5671(14)00051-3

Sharma, S. (1993). Behind the diffusion curve: an analysis of ATM adoption. Ssrn Electronic Journal, 1510(1-2), $152-166$

Sullivan, R. J. (2000). How has the adoption of internet banking affected performance and risk in banks?. Financial Industry Perspectives, 1 .

Sohail, M. S., \& Shanmugham, B. (2003). E-banking and customer preferences in Malaysia: An empirical investigation. Information sciences, 150(3), 207-217. https://doi.org/10.1016/S0020-0255(02)00378-X

Sullivan, R., \& Wang, Z. (2005). Internet banking: An exploration in technology diffusion and impact. Federal Reserve Bank of Kansas City Payments System Research Working Paper, 05-05.

Serener, B. (2016). Statistical Analysis of Internet Banking Usage with Logistic Regression. Procedia Computer Science, 102, 648-653. https://doi.org/10.1016/j.procs.2016.09.456

Takieddine, S., \& Sun, J. (2015). Internet banking diffusion: A country-level analysis. Electronic Commerce Research and Applications, 14(5), 361-371. https://doi.org/10.1016/j.elerap.2015.06.001 


\section{Other References}

Gujrati, D.N. (2004), Basic Econometrics, 4th ed., Tata McGraw-Hill, New Delhi.Lea, M. (1996), "Innovation and the cost of credit: a historical perspective". Housing Policy Debate, 7(1), 147-74.

Banking sector reforms by Ishrat Hussain. Journal of political economy, 106(5), 2006. 